INFO ARTIKEL

Riwayat Artikel:

Diterima : 1 Agustus 2019

Disetujui : 15 Agustus 2019

\title{
GEOGRAFI
}

\section{PERSEPSI MASYARAKAT MENGENAI MIGRASI SIRKULER DI DESA INDRAPURA KECAMATAN MUARA SUGIHAN KABUPATEN BANYUASIN}

\author{
Siti Evi Karunia Wati $^{1}$, Heri Setianto ${ }^{2}$ \\ ${ }^{1-2}$ Program Studi Pendidikan Geografi, Universitas PGRI Palembang \\ $(\square)$ setianto.heri8@gmail.com
}

\begin{abstract}
ABSTRAK
Penelitian ini bertujuan untuk mengetahui persepsi masyarakat mengenai migrasi sirkuler yang terjadi di desa Indrapura Kecamatan Muara Sugihan Kabupaten Banyuasin. Metode yang digunakan dalam penelitian ini menggunakan metode Deskriptif Kualitatif. Penelitian menggunakan responden sebanyak 20 anggota masyarakat. Teknik pengumpulan data yang digunakan yaitu teknik observasi, teknik wawancara dan teknik dokumentasi. Hasil penelitian menunjukkan bahwa 100\% masyarakat melakukan migrasi sirkuler dikarenakan upah kerja yang didapat kecil atau sedikit di desa, $70 \%$ alih fungsi sawah menjadi perkebunan, $45 \%$ tidak memiliki keahlian khusus. Selain itu $100 \%$ masyarakat mengatakan dampak adanya migrasi sirkuler yang dilakukan masyarakat yakni tidak dapat berperan aktif dalam masyarakat.Berdasarkan hasil penelitian dapat diketahui bahwasanya persepsi masyarakat Desa Indrapura akan tetap melakukan migrasi sirkuler dikarenakan beberapa faktor seperti upah kerja di desa lebih kecil, alih fungsi sawah menjadi perkebunan dan tidak memiliki keahlian khusus. Karena itu sebagian masyarakat tidak dapat berperan serta dalam membangun desa.
\end{abstract}

Kata Kunci: Persepsi, Migrasi Sirkuler

\section{PENDAHULUAN}

Persepsi sosial yaitu proses seseorang untuk mengetahui dan menginterpretasikan orang lain yang dipersepsi tentang sifatnya, dan kualitasnya yang ada dalam diri seseorang yang dipersepsi seperti yang telah disebutkan menurut Akbar, (2015) persepsi merupakan pendapat seseorang yang diintepretasikan sebagai tanggapan atau penerimaan langsung dari penglihatan suatu objek. Persepsi seseorang dalam menangkap informasi dan peristiwa-peristiwa dipengaruhi oleh tiga faktor, yaitu : 1) orang yang membentuk persepsi itu sendiri, 2) stimulus yang berupa obyek maupun peristiwa tertentu 3) stimulus dimana pembentukan persepsi itu terjadi, baik tempat, waktu dan suasana Muhyadi (1989, dikutip dari Achmad et al, 2012).
Masyarakat adalah suatu kesatuan hidup manusia yang meneempati suatu wilayah yang nyata, dan berinteraksi secara kontinyu sesuai dengan suatu sistem adat istiadat dan terikat oleh suatu rasa identitas komunitas Mclver \& Page (1937, dikutip dari Koentjaraningrat, 2005). Masyarakat merupakan sekelompok manusia, yang tinggal dalam satu wilayah yang memiliki tujuan yang sama dan adat tradisi yang sama pula (Sumaatmadja 2001). Di Desa Indrapura yang merupakan salah satu desa di Kecamatan Muara Sugihan Kabupaten Banyuasin dengan luas wilayah $3,397.47 \mathrm{Km}^{2}$ memiliki jumlah penduduk 2314 jiwa (BPS, 2018).

Masyarakat Desa Indrapura mayoritas bekerja sebagai petani, pengaruh migrasi sirkuler terhadap 
pertanian dimulai saat adanya pergeserankesempatan kerja dari sektor pertanian ke sektor non pertanian.Di Desa Indrapura ini, gejala penurunan jumlah tenaga kerja petani dari waktu ke waktu ini diduga karena rendahnya minat masyarakat untuk menjadi petani terutama kaum muda. Yang menjadi penyebab lain berkurangnya kesempatan kerja di desa karena mereka memperkenalkan teknologi baru pada bidang pertanian di desa. Pada saat musim panen usai, masyarakat lebih memilih bermigrasi keluar desa dengan menjadi buruh dengan keahlian dan pendidikan yang terbatas.

Migrasi sirkuler adalah gerak penduduk dari suatu wilayah menuju ke wilayah lain dengan tidak ada niatan menetap di daerah tujuan. Pengertian lain dari migrasi sirkuler jenis mobilitas penduduk yang dipilih seseorang atau kelompok dengan maksud untuk tidak menetap di daerah tujuan dan pada waktu tertentu tetap kembali ke daerah asal (Mantra, 2000). Migrasi yang terjadi dalam satu negara misalnya, antar provinsi, kota, atau kesatuan administratif lainnya biasa disebut dengan migrasi intern (Munir,2007)sama halnya yang dilakukan kebanyakan masyarakat Desa Indrapura yang melakukan migrasi sirkulerke Bangka Belitung. Orang yang berpindah tempat tetapi tidak bermaksud menetap di tempat tujuan disebut migran sikuler biasanya adalah orang yang masih mempunyai keluarga atau ikatan dengan tempat asalnya seperti petani, tukang becak, kuli bangunan, dan pengusaha warung tegal, yang sehari-harinya mencari nafkah di kota dan pulang ke kampungnya setiap bulan atau beberapa bulan sekali (Siswono, 2015).

\section{METODOLOGI PENELITIAN}

Objek dalam penelitian ini adalah Persepsi masyarakat desa Indrapura Kecamatan Muara Sugihan Kabupaten Banyuasin mengenai migrasi sirkuler.Penelitian ini menggunakan metode deskriptif kualitatif.Metode kualitatif adalah metode penelitian yang menggunakan pengamatan, wawancara, atau penelaah dokumen dan Deskriptif adalah data yang berupa kata-kata, gambar, dan bukan angka-angka (Moleong, 2017).
Teknik pengambilan data dalam penelitian ini dengan menggunakan teknik wawancara, observasi dan dokumentasi.Wawancara dilakukan kepada 20 responden yang dipilih dengan menggunakan metode Snowball Sampling yaitu teknik penentuan sampel yang mula-mula jumlahnya kecil, kemudian membesar. Dalam menentukan sampel mula - mula dipilih satu orang kemudian karena dirasa informasi yang didapat belum cukup peneliti memilih orang yang dianggap mampu melengkapi informasi yang diperoleh sebelumnya (Sugiyono, 2011).

\section{HASIL DAN PEMBAHASAN}

Migrasi sirkuler adalah gerak penduduk dari suatu wilayah menuju ke wilayah lain dengan tidak ada niatan menetap di daerah tujuan dan pada waktu tertentu akan kembali ke daerah asal. Fenomena migrasi sirkuler tersebut terjadi di Desa Indrapura.Didapat dari hasil wawancara dengan 20 responden $95 \%$ mengatakan bahwa masyarakat memperhatikan benar adanya fenomena migrasi sirkuler terjadi di Desa Indrapura.

Alasan masyarakat melakukan migrasi sirkuler:80\% masyarakat mengatakan migrasi sirkuler dilakukan sebagai matapencaharian;65\% masyarakat mengatakan migrasi sirkuler dilakukan sebagai masa tunggu tanam padi;55 \% masyarakat mengatakan migrasi sirkuler dilakukan sebagai penambah penghasilan; $10 \%$ masyarakat mengatakan migrasi sirkuler dilakukan karena untuk menambah pengalaman.

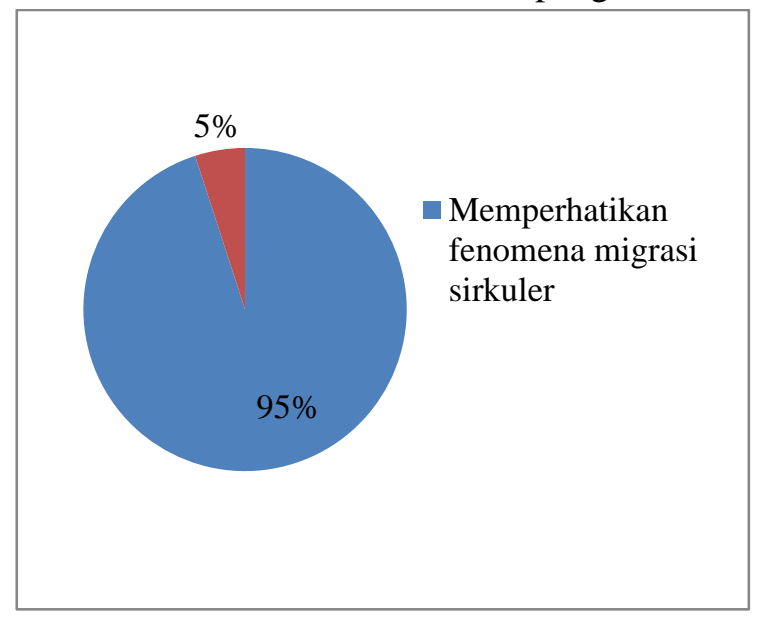

Gambar 1. Diagram Prosentase Masyarakat yang Aktif dalam Migran Sirkuler 
Menurut Purwanto (37 tahun) "Karena sudah seperti menjadi kebiasaan bagi sebagian masyarakat hampir saya tidak memperhatikan hal tersebut bahkan setelah mbak tanya inilah saya mulai terpikirkan bahwa memang benar adanya fenomena migrasi sirkuler yang terjadi di desa ini”.

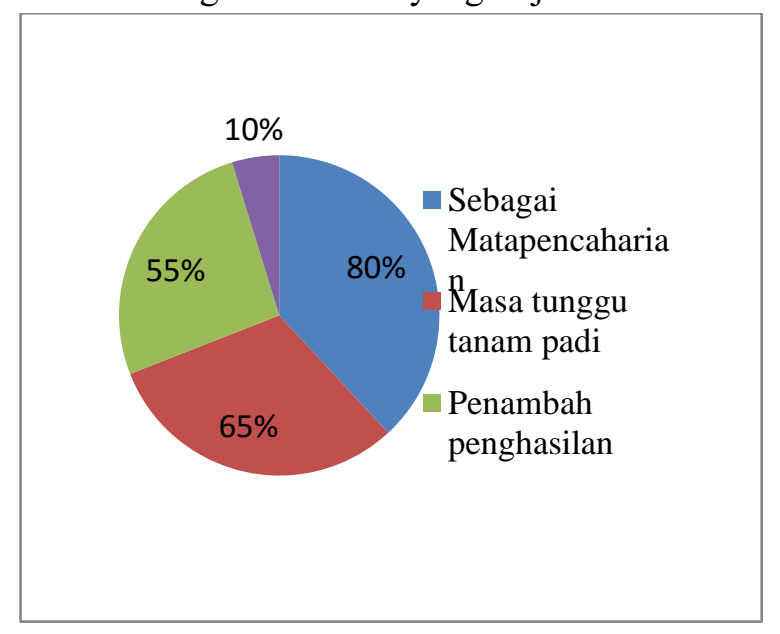

Gambar 2. Alasan masyarakat melakukan migrasi sirkuler

Menurut ibu Siti Munawaroh (37 tahun) "Suami saya melakukan migrasi sirkuler dikarenakan masa tunggu tanam padi yang akan mulai menanam ketika bulan rendeng nanti". Sedangkan menurut Andika (19 tahun) Saya melakukan migrasi sirkuler ke Bangka diajak oleh ayah saya untuk menambah pengalaman karena di desa saya juga sudah tidak melanjutkan sekolah, lebih baik saya pergi ke Bangka saja disana lebih banyak tempat wisata tidak jenuh seperti dijalur.

Faktor pendorong masyarakat untuk melakukan migrasi sirkuler yaitu, $70 \%$ masyarakat mengatakan migrasi sirkuler dilakukan sebagai dampak alih fungsi lahan; $100 \%$ masyarakat mengatakan migrasi dilakukan karena upah kerja di desa lebih kecil dibanding daerah tujuan; $45 \%$ masyarakat mengatakan migrasi sirkuler dilakukan karena tidak memiliki keahlian khusus; $75 \%$ masyarakat mengatakan migrasi sirkuler dilakukan karena tidak memiliki modal untuk buka usaha.; dan $75 \%$ masyarakat mengatakan migrasi sirkuler dilakukan karena tidak ada lapangan pekerjaan di desa.

Dampak migrasi sirkuler,100\% masyarakat mengatakan bahwa pelaku migrasi sirkuler tidak dapat berperan aktif dalam masyaraka;100\% masyarakat mengatakan bahwa keluarga yang ditinggalkan merasa tidak aman; dan 100\% masyarakat mengatakan pelaku migrasi sirkuler lamban dalam menerima informasi terbaru pemerintahan desa.

Menurut Mufarida (42 tahun) Orang memilih melakukan migrasi sirkuler itu dikarenakan banyak sawah yang sudah berubah menjadi perkebunan karet dan sawit sehingga mereka tidak memiliki pekerjaan lagi di desa yang kemudian membuat keputusan untuk melakukan migrasi sirkuler untuk memenuhi kebutuhannya.

Sedangkan menurut Ira Khoiriyah (38 tahun) Orang yang melakukan migrasi sirkuler tidak dapat berperan aktif dalam masyarakat karena dirinya selalu tidak ada di rumah terutama pada kegiatan rutinitas yang ada di desa Indrapura misalnya, yasinan, dzikir manaqib, kerja bakti, atau yang lainnya karena tidak tentu berada di rumah.

Kemudian manfaatmigrasisirkulerbagi yang melakukannya, $100 \%$ masyarakat mengatakan manfaat migrasi sirkuler bagi pelaku migrasi sirkuler dan keluarga yang ditinggalkan yakni tetap terpenuhinya kebutuhan sehari - hari sedangkan untuk masyarakat lain yang melihat fenomena migrasi sirkuler tidak ada manfaatnya.

Selanjutnyakesejahteraankeluarga yang ditinggalkan melakukan migrasi sirkuler, $75 \%$ masyarakat mengatakan mereka yang melakukan migrasi sirkuler dikatakan keluarga yang belum sejahtera; dan $25 \%$ masyarakat mengatakan mereka yang melakukan migrasi sirkuler dikatakan keluarga yang tidak sejahtera.

Menurut Kusniati (27 tahun) Manfaat dari migrasi sirkuler yang dilakukan suami saya yakni tetap terpenuhinya kebutuhan sehari - hari keluarga saya. Meski yang sebenarnya keluarga saya belum bisa dikatakan sejahtera karena masih saja suami saya terus melakukan migrasi sirkuler setiap tahunnya karena menunggu masa tanam padi yang cukup lama juga. 


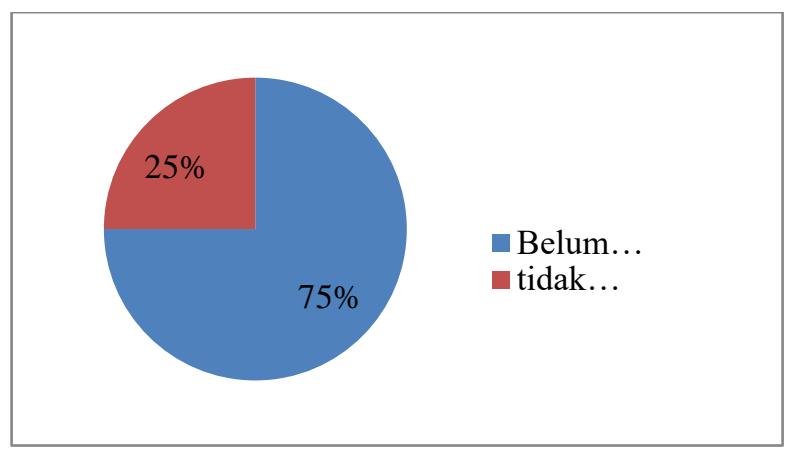

Gambar 3. Kesejahteraan keluarga yang ditinggal melakukan migrasi sirkuler

Menurut Trihono (31 tahun) dengan saya melakukan migrasi sirkuler semua kebutuhan keluarga saya tentu saja tetap terpenuhi dan tidak hanya mengandalkan hasil dari perkebunan yang saya punya. Namun, yang sebenarnya keluarga saya masih belum bisa dikatakan sejahtera ,sebenarnya saya sudah tidak mau lagi melakukan migrasi sirkuler ingin membuka usaha di rumah tetapi karena kebutuhan keluarga yang setiap tahun meningkat sampai -sampai tidak bisa lagi untuk mengumpulkan modal dan sampai sekarang saya masih melakukan migrasi sirkuler mungkin sebentar lagi saya juga akan berangkat dan akan pulang kembali dekat lebaran nanti.

\section{SIMPULAN}

Berdasarkan hasil penelitian dan pembahasan dapat disimpulkan sebagai berikut:

1. Masyarakat masih melakukan migrasi sirkuler dikarenakan upah kerja yang didapat kecil atau sedikit di desa.

2. Alih fungsi sawah menjadi perkebunan, dan tidak memiliki keahlian khusus menyebabkan masyarakat di Desa Indrapura masih melakukan migrasi sirkuler demi memenuhi kebutuhan hidup.

3. Sebagian dari masyarakat tidak menginginkan terjadinya fenomena migrasi sirkuler, namun karena keterbatasan keahlian masyarakat dan juga masa tunggu tanam padi yang cukup lama sehingga masyarakat tetap memilih untuk melakukan migrasi sirkuler.

\section{DAFTAR PUSTAKA}

Akbar, R. F. (2015). Analisis Persepsi Pelajar Tingkat Menengah Pada Sekolah Tinggi Agama Islam Negeri Kudus. Stain Kudus, 10(1), 189-210.

BPS Kecamatan Muara Sugihan Dalam Angka. (2018). BPS Kab. Banyuasin.

Koentjaraningrat. (2005). Pengantar Antropologi. Jakarta: PT. Asdi Mahasatya.

Mantra, I.B. 2000. Demografi Umum. Yogyakarta: Pustaka Ilmu

Munir, Rizky. (2007). Dasar- Dasar Demografi. Jakarta : FEUI

Moleong, L. J. (2017). Metodologi Penelitian Kualitatif. Bandung: PT.Remaja Rosdakarya.

Nursid Sumaatmadja. 2001. Metode Pembelajaran Geografi. Bumi Aksara. Jakarta

Sudijono, Anas. (2015). Pengantar Statistik Pendidikan. Jakarta:PT Raja Grafindo Persada.

Siswono, E. (2015). DEMOGRAFI. Yogyakarta: Ombak Dua.

Sugiyono. (2011). Metode Penelitian Kuantitatif, Kualitatif, dan R\&D. International Journal of Management. Bandung: ALFABETA. 